\title{
KENOTIC THEOLOGY IN THE EASTERN CHURCH HYMNS
}

\author{
Fr. Prof. PhD Nicuşor TUCĂ, \\ Faculty of Orthodox Theology "'Ovidius" University of Constanta, \\ ROMANIA \\ Email: tucanicusor@yahoo.com
}

\begin{abstract}
The hypostatic or personal union (enosis ipostatiki) is the wreath and the bond between man and God. The consequences of the hypostatic union form the object of most of the hymns from the cultic treasure of the Eastern Church. The theandric person of our Saviour Jesus Christ is intrinsically present under one form or the other in all the hymns of our Church. Kenosis represents one of the consequences of the hypostatic union and a profound expression of God's supreme love for mankind. The Orthodox teaching - both in dogma and in divine service - is against a radical kenosis that would nullify the sense of Jesus' Embodiment as overflowing of the divine energies in the world and in mankind.
\end{abstract}

Keywords: kenosis (self-emptying /humility/descent); hypostatic or personal union; dogma; hymnography;

\section{INTRODUCTION}

The Saviour Jesus Christ is truly God and truly man, is the God-man, with two natures, divine and human, united in one person or hypostasis, the person of God-the Logos. This union between the God's Son or Logos and human nature in Jesus Christ is called hypostatic or personal union (enosis ipostatiki).

The hypostatic union has realized the maximal bond and communion of man with God in Christ, being, thereafter, the model and strength of the moral union of man with God. Man has the mission to unite, by grace, his will, to God's will, "according to the image of God's Son", remaining always in communion with God, just as Christ, by the hypostatic union, perfectly united the human will with the divine will. The dogma of the hypostatic union was stated at the Third Ecumenical Council (431) and developed and clarified at the Fourth and Sixth Ecumenical Councils. The consequences of the hypostatic union are the object of the majority of the hymns in the cultic treasure of our Church. The theandric person of the Saviour Christ is present intrinsically under one form or the other in all the hymnographic creation. The consequences of the hypostatic union highlight, in a special way, the mystery of the unity between the Person of Jesus Christ and His community of human being with us, by keeping His community of Divine Being with the Father and with the Holy Spirit. All these explicit the salvation mystery realized by Jesus Christ, in its main aspect, turned to the human nature. Christ would not save us, had He manifested Himself as purely divine, by the features and acts of the divine nature to us, and as purely human, by the features and acts of His human nature ${ }^{1}$.

\footnotetext{
${ }^{1}$ Pr. Prof. Dumitru Stăniloae, Teologia Dogmatică Ortodoxă, Editura Institutului Biblic şi de Misiune al Bisericii Ortodoxe Române, București, vol. II, $1997^{2}$, p. 72.
} 
The embodied Son of God, Jesus Christ, remains, also after the Embodiment, one of the three hypostases of the Holy Trinity in community of being also with us as a man. Therefore, by the Embodiment, neither His hypostasis, nor His divine nature were altered ${ }^{2}$.

The hypostatic union realized a maximal union between divine and human, with no mixture and no separation, or, in other words, with no confusion. The divine and the human, profiting each other mutually, reveal the aim of the creation or generation of the human.

\section{KENOSIS - A CONSEQUENCE OF THE HYPOSTATIC UNION AND A DEEP EXPRESSION OF THE SUPREME LOVE OF GOD FOR MANKIND}

Kenosis (from Gr. Keneo = to empty oneself, to pour oneself out) is the most adequate modality chosen by God to reveal Himself, according to our capacity of understanding the divine. Kenosis is the fundamental antinomy of the Holy Scripture. But what does this antinomy represent? It is affirmed at the same time that God is unseen in His being, but also that God showed Himself by Jesus Christ. This antinomy is clearer in the New Testament. The affirmation: "No one has ever seen God at any time" (John 1: 17), as "He dwells in unapproachable light" (1 Timothy 6:16), stays next to "Great is the mystery of godliness: God was manifested in the flesh" (1 Timothy 3:16), He manifested Himself by His Son, Who says: "He who has seen Me has seen the Father" (John 14: 9). It results from here that while logically any antinomy implies a contradiction, biblically and theologically, nevertheless, the two affirmations stand together, expressing a perfect truth. The fact that God is at the same time not seen and perceivable, and that His relationship with us cannot be expressed in any other way except antinomically, demonstrates that this descent of the Son to us, is not just a theory, but a testimony revealing the love of God Who created us ${ }^{3}$.

Kenosis cannot be, at the same time, seen as an inner absence of God and it is out of the question for this descent to have occurred up to a sort of limiting of the divine nature, for it to get to the measure of our nature, as some older or newer kenotic theories appreciate ${ }^{4}$.

Kenosis is an act of freedom and love, showing God's initiative for man's salvation ${ }^{5}$.

From this perspective, kenosis appears as the maximal expression of God's love and generosity by humility. "All the mystery of the oikonomia", says Saint Cyril of Alexandria, "lies in God's Son's emptying Himself and making Himself little"6. Only out of full obedience to God the Father and out of love for mankind, the Son accepted to take on the humble image of God's service (Isaiah 49: 3) and to make Himself our servant".

The Saviour's life can be divided into two states: one of humility, or "Self-emptying" (kenosis), and the other, of glorification. The kenotic state starts at His Embodiment and lasts His whole life, culminating with the death on the cross. The state of glorification includes His descent to hell, Resurrection, Ascension and seating on the right of the Father.

The assuming or taking on of the human nature by God's Son at His Embodiment (Luke 1: 35) and the human nature showing Him at His birth as a man in everything just like

\footnotetext{
${ }^{2}$ Dragoș Bălan, Curs de teologie dogmatică și simbolică, vol. I, Editura Globe Edit, Berlin, 2018, p. 109.

${ }^{3}$ Pr. Prof. Dr. Constantin Galeriu, Jertfă și răscumpărare, Editura "Harisma”, București, 1991, p. 121.

${ }^{4}$ Stan R. Coman, "Sensul ortodox al chenozei față de teoriile chenotice modern", in Ortodoxia, 5/3 (1956), pp. 417-431.

${ }^{5}$ Pr. Prof. Dr. Constantin Galeriu, Jertfă și răscumpărare, pp. 121-123.

${ }^{6}$ Cited after Vladimir Lossky, Teologia mistică a Bisericii de Răsărit, translation, introductory study and notes by Fr. Vasile Răducă, Editura "Anastasia”, București, (f.a.), p. 173.

${ }^{7}$ Ieromonahul Antonie Plămădeală, "Câteva probleme în legătură cu Ebed-Iahve și Deutero-Isaia. Preliminarii la o teologie a slujirii”, in Mitropolia Banatului, 20/1-3 (1970), p. 70 sqq.
} 
us, except for sin (John 8: 46), constitutes His "kenosis" or "Self-emptying" of the grace which He had before the embodiment (John 17: 5).

On the other hand, kenosis is the state of humility and dwindling that the Son of Man assumes in His embodiment, as an act of submission to God the Father. Namely God, in the person of the Embodied Son, partakes of the condition of the sinful man, to pass him over to the divine condition. This descent katabasis makes the exchange of conditions possible: from the state of sin into the state of grace, which gives access to the communication of the divine nature (2 Peter 1: 4).

It is a state that cannot be understood and described adequately. In the systematic theology, kenosis does not lie in the hypostatic union in itself, but is a consequence of it.

\section{REFLECTION OF THE KENOTIC THEOLOGY IN THE LITURGICAL HYMNS}

In Christ, God becomes a partaker of man's condition of sinner and mortal (Hebrews 2: 9), to give him the possibility to pass over to God. In His Embodiment, God "conceals" His Divinity, to descend to the state of man, taking on the image of "servant" dikonos. "The unencompassable Logos of the Father, has been encompassed, O Theotokos, from you, taking on a human body; and making the dirtied image return to the first image, He mixed it with divine adornment. Therefore, confessing the salvation, we affirm Him by deeds and words" ${ }^{8}$, that the Son of God may be identified with the Son of Man. He descended bending down the heavens katabasis), to show that salvation is not imagination (fantasia), but a reality and an act of obedience.

God-the Logos descends to us because we were not able to ascend to Him, showing to us, as the hymnographer says, the way to God: "The Word who humbled Himself even to the form of a servant showed that humility is the best path to exaltation. Every man, then,

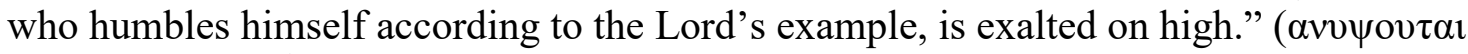
$\tau \alpha \pi \varepsilon(v 0 v \mu \varepsilon v o \varsigma)^{69}$.

Therefore, the incarnation means voluntary "descent", kenosis. "The Kenosis of the Son of God initiated by God the Father, performed in the Son by the Holy Spirit reveals the other-worldly absolute freedom of God, Who is not opposed to His creation but can place Himself within the hierarchical order established by Him at creation, leading the "beloved one" (mankind) to His boundless love and goodness. Considering this reason of creation, the Reason -above the heavenly minds - does not bear separation or change but restores man in his status as a being modeling himself in harmony with God's will and with the commandment of sacrificial love." 10

In the act of the embodiment, the Son humbled Himself, "taking on the image of a servant" (Philippians 2: 7). He hides His power and His grace in order not to humble the people. God showed Himself to the people physically: "God sent Him: as a man to mankind He sent Him“"11. Saint Isaac the Syrian says that, in fact, kenosis, humility, is God's apparel: "Because the Logos, assuming a human body, put on this apparel and by it spoke to us in our body and whoever put on this apparel, truly became like Him Who descended from His

\footnotetext{
${ }^{8}$ Triod, Editura Institutului Biblic şi de Misiune al Bisericii Ortodoxe Române, București, 2000 ${ }^{9}$, Duminica I a Postului, la Utrenie, condacul, p. 210.

${ }^{9}$ Triod, Duminica Vameșului și a Fariseului, la Utrenie, cântarea a IV-a de la canon, stihira 1, p. 9; Cf.

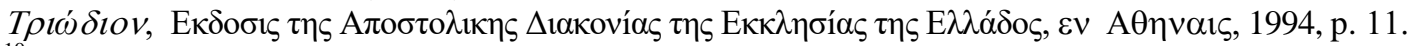

${ }^{10}$ Ionuț Chircalan, Creator şi creaţie: părintele Dumitru Stăniloae - valorificator al scrierilor areopagitice, Editura Universitară, București, 2021, p. 161.

${ }^{11}$ Epistola către Diognet, VII, 1, P.G. II, ed. F. X. Funk, Patres Apostolici, vol. I, Tübingen, 1901, pp. 390413.
} 
greatness and hid the power of His greatness and covered his glory in humble thinking. Because creation would not have been able to behold Him, had He not taken on a part of it and had He not spoken to it in this way; neither would it have been able to listen to the words of His mouth, face to face" ${ }^{\prime 2}$.

To enter the space of creation, namely the domain of oikonomia, God "compresses" Himself, He diminishes His stature, He decreases His dimensions, He "modifies" Himself $\mathrm{f}^{13}$. This is the state of kenosis (Philippians 2: 6), of restraint, namely of humility up to death. Kenosis is part of the logic of the oikonomia of the Embodiment; God enters the world willingly by the narrow gate of the Embodiment to make "the growth in Christ" possible (1 Corinthians 3: 6-7): "The nature of man, and that of the angels, $\mathrm{O}$ Benefactor, feel that the words are not enough to thank You for Your mercy; because, with Your body, You have willingly made Yourself poor for us and have hanged Yourself on wood, making Yourself cursed to take away the initial curse mankind was under."14

"He Who put on our weakness is Emmanuel", God coming down to us. The Fathers speak about God's "humbling Himself", yet this has the purpose not just of giving an example of humility and service, but also of making room for human nature and freedom to unfold to the maximum in their width and strength. A sticheron of the Great Canon affirms this real and authentic humanity of Jesus: "Christ became man and shared in my flesh; and willingly He performed all that belongs to my nature, only without sin. He set before thee, my soul, an example and image of His condescension." 15

In His kenosis, the Saviour of life takes on Himself the consequences of sin, going up to tasting death willingly, in front of death experiencing the natural fear: "Fear of death is an attribute of nature, which entered into nature by disobedience. And trembling in front of death is a sign of unrepented sins. Christ has fear of death, yet He does not tremble, therefore we can clearly see the features of the two natures" ${ }^{16}$.

Based on the text in Philippians 2: 7-8, a great number of ecclesial texts highlight the state of continual sacrifice here on Earth, to which God the Word consented, up to its full consumption on Golgotha: "Ineffable is the condescension of the Word of God. Chirst is Himself both God and man; yet He counted not His Godhead a thing to be seized and held fast, and this He showed to His disciples by taking the form of a servant $<$ for He has been greatly glorified." 17

The same expression of Paul, "the image of a servant" can be found in many other liturgical songs: "...You Who have made the heavens bend down and have descended... Who humbled Yourself willingly and took on the image of a servant..."18

\footnotetext{
${ }^{12}$ Sf. Isaac Sirul, Cuvânt despre nevoință, XX, in "Filocalia românească", vol. 10, translation, introduction and notes by Fr. Prof. Dumitru Stăniloae, Editura Institutului Biblic şi de Misiune al Bisericii Ortodoxe Române, București, 1981, p. 105.

${ }^{13}$ Pr. Prof. Dr. Ion Bria, "Iisus Hristos - Dumnezeu Mântuitorul. Hristologia”, in Studii Teologice, 43/2 (1991), p. 36.

${ }^{14}$ Triod, vineri în săptămâna lăsatului sec de brânză, cântarea a IX-a, tricântarea, irmosul, p. 81.

${ }^{15}$ Triod, marți în întâia săptămână a postului, la Canonul cel Mare, cântarea a IX-a, stihira a 7-a, p. 135.

${ }^{16}$ Sf. Ioan Scărarul, Scara, Cuv. VI, 3-4, in "Filocalia românească", vol. 9, translation, introduction and notes by Fr. Prof. Dr. Dumitru Stăniloae, Editura Institutului Biblic şi de Misiune al Bisericii Ortodoxe Române, București, 1980, p. 156.

${ }^{17}$ Triod, luni, Săptămâna Patimilor, la Utrenie, tripesnițul lui Cosma de Maiuma, oda I, sihira 2, p. 475

${ }^{18}$ Triod, mucenicina de joi seara, a V-a săptămână a Postului Mare, p. 402; Liturghier, ed. îngrijită de Pr. Prof. Dr. Nicolae D. Necula, Editura Institutului Biblic și de Misiune al Bisericii Ortodoxe Române, București, 2000, rugăciunea hristologică din Liturghia Sfântului Vasile cel Mare, pp. 228-229.
} 
Then, we meet the other equivalent expressions: "He humbled Himself in His ineffable kenosis"19, "He showed Himself on Earth and spent time with the people"20, "by benevolent poverty, making Himself accursed, to take up the curse of the world, humbling Himself to death on the cross. O, Mystery! The way of kenosis is unknown. The way of His birth, ineffable! ... The Logos ineffably above nature takes on the image of the servant..." ${ }^{\text {"21 }}$

But Jesus the Man and the Logos, facing the human passions and affects, bearing them, defeats them, just as He will defeat death itself and so, the theological thinking can take note of this apparent paradox, that kenosis is the way of victory and of glory. The same is taught by the Church hymnography: "Having assumed all things that pertain to man, and taken upon Thee all that is ours, thou didst deign to be nailed to the Cross, $O$ my Creator, accepting to endure death as a man, that as God Thou mightest deliver humanity from death; wherefore, we cry out to Thee as to the Bestower of life: Glory to Thy compassion, $\mathrm{O}$ Christ!" - a sedealna highlights ${ }^{22}$.

A troparion speaks about the conquest of the human affects, in this pointed game of meanings of the kenosis: "While sharing the sufferings through Thy sufferings, Thou didst remain untouched by the passions, O Word of God; yet as Thou art suffering for the passions, Thou dost loose man from the passions, O our Servior; for Thou alone art dispassionate and almighty." ${ }^{23}$.

And regarding the ascent that humility (kenosis) leads to, the Church songs confirm it when they say: "You have shown humility to be the good way of the ascent, humbling Yourself willingly and taking on the image of a slave..." 24

In other hymns, humility is portrayed precisely according to the word of the Scripture (2 Corinthians 8: 8), as poverty taken upon himself willingly by the rich one: "The Rich One has made Himself poor, impoverishing those who get themselves rich in evilness; God makes Himself known as a man through the Virgin, who remains untouched and unchanged, let us all praise Him with songs, for He has glorified Himself beyond words" ${ }^{25}$.

$* * *$

The explanations that have been given of God-the-Logos showing Himself physically (John 1: 14) and therefore of the kenosis of the Son of God in the field of the protestant theology, "starting with the $16^{\text {th }}$ century to this day, are not in agreement with the dogma of the hypostatic union and, consequently, with the Orthodox teaching about it, altering or losing the sense of the dogmatic definition of Chalcedon ${ }^{\text {“626. }}$.

Starting from the conception of Luther, according to which the human nature receives in Christ divine features (becomes omnipresent), the Protestant Christians „understand kenosis either as an emptiness of use, i.e. although human nature possesses divine properties, they are not shown or are not used completely and continuously (Giessen

${ }^{19}$ Octoih, Editura Institutului Biblic și de Misiune al Bisericii Ortodoxe Române, București, $1975^{6}$, glasul al VIII-lea, sâmbătă la Vecernia mică, Slavă... Și acum..., de la „Doamne, strigat-am, pp. 642-643.

${ }^{20}$ Octoih, glasul al VIII-lea, sâmbătă la Vecernia mare, Slavă... Și acum... Dogmatica, pp. 644-645.

21 Penticostar, Editura Institutului Biblic și de Misiune al Bisericii Ortodoxe Române, București,1999 ${ }^{8}$, miercurea înjumătățirii praznicului Paștilor, la Utrenie, oda a IX-a, stihira a 3-a, p. 163.

${ }^{22}$ Penticostar, duminica a IV-a după Paști, sedelna după a II-a stihologie, la Utrenie, p. 133.

${ }^{23}$ Penticostar, duminica a VII-a după Paști, la Utrenie oda a IX-a, stihira 1 p. 284.

${ }^{24}$ Triod, luni, la Utrenie, a IV-a săptămână a Postului Mare, prima samoglasnică de la stihoavnă, p. 328.

${ }^{25}$ Triod, luni, Săptămâna Patimilor, la Utrenie, tripesnițul lui Cosma de Maiuma, oda I, sih. 1, p. 475.

${ }^{26}$ Pr. Prof. Dr Dumitru Radu et. al., Indrumări misionare, Editura Institutului Biblic și de Misiune al Bisericii Ortodoxe Române, București, 1986, pp. 326-327. 
School) or as concealment of use, i.e. human nature makes only a hidden use, mysteriously, by the divine attributes received (Tübingen School). However, it has been observed that a kenosis as an emptiness of use, distinguishing between what is used and what is not used, leads to the opinions professed by Nestorianism. And, on the other hand, kenosis as concealment of use leads to doketism". In this case, the following question arises: «Either the passions of the Lord are apparent, or we must admit two human natures into Christ, one hidden and one visible»." ${ }^{27}$

Later, in the nineteenth century, beginning with G. Thomasius, kenotic theories "extended the kenosis to the divine nature itself, stating that it would have been diminished or narrowed by the Incarnation of the Son of God. They understand kenosis in a radical sense. That is, the Logos-incarnate retains the divine nature, but He benevolently selfmarginalizes, renouncing the updating of His attributes, as omnipotence, omnipresence, omniscience, so that he can transpose Himself into the plane of human life (Thomasius). In the state of kenosis, add these thinkers, the Son of God incarnate, that is, Jesus Christ, is only virtually God, not having the consciousness that $\mathrm{He}$ is God and being limited by the natural conditions of the earthly life (Gess)" 28 , this leading to a new form of monophysitism according to which in Jesus Christ on earth the divine nature is absent, while in heaven, the human nature lacks. ${ }^{29}$

In contemporary Protestant theology, the legitimate protest of the "dialectical" theology of K. Barth, E. Brunner, and other more traditionalist theologians such as Paul Althaus, E. Schlink, W. Pannenberg, rose against an anthropological reduction of Christianity, who argued vehemently in their work for a return to the dogma of Chalcedon. Positive in intention, this return is only partially complete and limited, as, on the one hand, it returns only to the letter of the definition of 451, detached and absolutized from the context of the other subsequent Christological Councils (V and VI), and on the other hand, it receives interpretations foreign (if not contrary) to the spirit of the Holy Fathers in which it was originally expressed. Or, to substantiate a rigorous and consistent recourse to the dogmatic Symbols and definitions of Ecumenical Councils, Protestant theology must first reconsider the main theological question, decisive for the whole of contemporary ecumenism, i.e., the relationship between Scripture-Tradition-Church. ${ }^{30}$

\section{CONCLUSION}

Consequently, the Orthodox Church teaches, both in her dogma and in her cult, that the Saviour Christ, namely the New Adam, appropriating our human nature with all its passions (affects) except sin, or as the Church song says, assuming our body "except for uncleanness", began by His Own human nature the work of restoration, renewing Adam's nature in Himself by the gateway, full of humiliations and pains, of kenosis, and by His victory over sufferings and over death which shook the whole cosmos and renewed the laws

\footnotetext{
${ }^{27}$ Pr. Prof. Dr Dumitru Radu et. alii, Indrumări misionare, 326.

${ }^{28}$ Prof. Nicolae Chițescu, Pr. Prof. Isidor Todoran, Pr. Prof. I. Petreuță, Teologia Dogmatică și Simbolică, vol. II, Editura Institutului Biblic și de Misiune al Bisericii Ortodoxe Române, București, 1958, p. 601.

${ }^{29}$ Hristu Andruțos, Dogmatica Bisericii Ortodoxe Răsăritene, translated in Romanian by Fr. Prof Dumitru Stăniloae, Sibiu, 1930, p. 234.

${ }^{30}$ For the problems and difficulties of a current ecumenical reception of the Councils, see the report at the Geneva Colloquium of 1969, convened under the auspices of The Commission on Faith and Order of the World Council of Churches, "Le Concile de la Chalcedoine. Son histoire, sa reception par les Eglises et son actualité", in Irenikon, 44/3 (1971), pp. 349-366, summed up in Ortodoxia, 24/1 (1972), pp. 55-58.
} 
of nature, calling the people to collaborate, after having given them the possibility of their own restoration.

Kenosis is explained, from an Orthodox perspective, not referring to the divine or even human nature in Jesus Christ, but to the person. The example of the mother who descends to the child's level of understanding, yet without renouncing her state of mother, of person, is the most eloquent. The Orthodox teaching is against a radical kenosis which would nullify the Embodiment's sense as an overflow of the divine energies in the world and in man.

\section{BIBLIOGRAPHY:}

[1]. **** "Le Concile de la Chalcedoine. Son histoire, sa reception par les Eglises et son actualité", in Irenikon, 44/3 (1971), pp. 349-366.

[2]. Bălan, Dragoș, Curs de teologie dogmatică și simbolică/Course of Dogmatic and Symbolical Theology, vol. I, Editura Globe Edit, Berlin, 2018.

[3]. Bria, Ion, "Iisus Hristos - Dumnezeu Mântuitorul. Hristologia"/Jesus Christ - the Saviour God. Christology, in Studii Teologice, 43/2 (1991), pp. 3-53.

[4]. Chircalan, Ionuț, Creator şi creație: părintele Dumitru Stăniloae - valorificator al scrierilor areopagitice/ Creator and Creation. Father Dumitru Stăniloae -A Valuer of the Areopagitic Writings, Editura Universitară, București, 2021.

[5]. Chițescu, Nicolae, Todoran, Isidor, Petreuță, I., Teologia Dogmatică și Simbolică/Dogmatic and Symbolical Theology, vol. II, Editura Institutului Biblic şi de Misiune al Bisericii Ortodoxe Române, București, 1958.

[6]. Coman, Stan R., "Sensul ortodox al chenozei față de teoriile chenotice modern" /The Orthodox Sense of Kenosis by Comparison with the Modern Kenotic Theologies, in Ortodoxia, 5/3 (1956), pp. 417-431.

[7]. Galeriu, Constantin, Jertfă și răscumpărare/Sacrifice and Ransom, Editura "Harisma“, București, 1991.

[8]. Andruțos, Hristu, Dogmatica Bisericii Ortodoxe Răsăritene/Dogmatics of the Eastern Orthodox Church, translated into Romanian by Dumitru Stăniloae, Sibiu, 1930.

[9]. Liturghier/Liturgy Book, edition supervised by Pr. Prof. Dr. Nicolae D. Necula, Editura Institutului Biblic şi de Misiune al Bisericii Ortodoxe Române, București, 2000.

[10]. Lossky, Vladimir, Teologia mistică a Bisericii de Răsărit/Mystic Theology of the Eastern Church, translation, introductory study and notes by Fr. Vasile Răducă, Editura "Anastasia", București, (f.a.).

[11]. Octoih/Octoechos, Editura Institutului Biblic și de Misiune al Bisericii Ortodoxe Române, București, $1975^{6}$.

[12]. Penticostar/Penticostarion, Editura Institutului Biblic și de Misiune al Bisericii Ortodoxe Române, București, $1999^{8}$.

[13]. Plămădeală, Antonie, "Câteva probleme în legătură cu Ebed-Iahve și Deutero-Isaia. Preliminarii la o teologie a slujirii" /Several Issues regarding Ebed-Isaiah and Deutero-Isaiah. Preliminaries to a Theology of Service, in Mitropolia Banatului, 20/1-3 (1970), p. 70-97.

[14]. Radu, Dumitru et. al., Îndrumări misionare/Missionary Guidelines, Editura Institutului Biblic și de Misiune al Bisericii Ortodoxe Române, București, 1986.

[15]. Sf. Ioan Scărarul, Scara/The Ladder, in „Filocalia românească”, vol. 9, translation, introduction and notes by Dumitru Stăniloae, Editura Institutului Biblic şi de Misiune al Bisericii Ortodoxe Române, București, 1980.

[16]. Sf. Isaac Sirul, Cuvânt despre nevoință/Discourse on the Holy Endeavours, in "Filocalia românească", vol. 10, translation, introduction and notes by Dumitru Stăniloae, Editura Institutului Biblic şi de Misiune al Bisericii Ortodoxe Române, București, 1981.

[17]. Stăniloae, Dumitru, Teologia Dogmatică Ortodoxă/Dogmatic Theology, Editura Institutului Biblic şi de Misiune al Bisericii Ortodoxe Române, Bucureşti, vol. II, $1997^{2}$.

[18]. Triod/Triodion, Editura Institutului Biblic şi de Misiune al Bisericii Ortodoxe Române, București, $2000^{9}$.

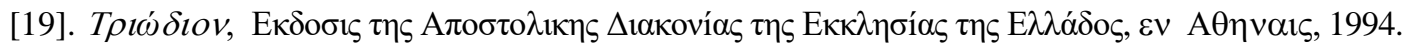

